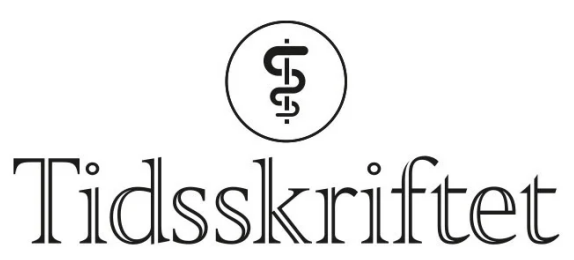

DEN NORSKE LEGEFORENING

\title{
Ei kvinne i 50-åra med hovudverk, uklart syn og utslett
}

NOE Å LARE AV

\section{ANDERS VIK}

Anders Vik(f. 1963) er ph.d., spesialist i indremedisin og i blodsykdommer, førsteamanuensis II ved Universitetet i Tromsø og seksjonsoverlege ved Seksjon for hematologi, Universitetssykehuset NordNorge.

Forfatter har fylt ut ICMJE-skjemaet og oppgir ingen interessekonflikter.

Email:anders.vik@unn.no

Hematologisk seksjon

Medisinsk klinikk

Universitetssykehuset Nord-Norge

\section{VIDAR ISAKSEN}

Vidar Isaksen (f. 1959) er spesialist i patologi og overlege ved Patologisk anatomisk avdeling, Universitetssykehuset Nord-Norge.

Forfatter har fylt ut ICMJE-skjemaet og oppgir ingen interessekonflikter.

Patologisk anatomisk avdeling

Universitetssykehuset Nord-Norge

\section{IAN BROX}

Jan Brox (f. 1950) er spesialist i medisinsk biokjemi, avdelingsoverlege ved Laboratoriemedisinsk avdeling Universitetssykehuset Nord-Norge og professor II ved Det helsevitenskapelige fakultet, Universitetet i Tromsø.

Forfatter har fylt ut ICMJE-skjemaet og oppgir ingen interessekonflikter.

Avdeling for medisinsk biokjemi

Universitetssykehuset Nord-Norge

\section{JOHN-BJARNE HANSEN}

John-Bjarne Hansen (f. 1961) er dr.med. og professor i hematologi. Han er forskningsgruppeleder ved Hematologisk forskningsgruppe, Det helsevitenskapelige fakultet, Universitetet i Troms $\emptyset$, og overlege ved Hematologisk seksjon, Medisinsk klinikk, Universitetssykehuset Nord Norge. Forfatter har fylt ut ICMJE-skjemaet og oppgir ingen interessekonflikter.

Hematologisk seksjon

Medisinsk klinikk

Universitetssykehuset Nord-Norge 


\section{Kvinna kontakta lege fordi ho var plaga av hovudverk, uklart syn og utslett. Ho fekk påvist sekundær hyperlipidemi og erytrocytose. Behandling med cellegift førte til normalisering av lipidverdiane, medan kirurgisk behandling gav tilbakegang av erytrocytosen.}

Ei kvinne i 5o-åra vart av fastlegen sendt til utgreiing ved medisinsk poliklinikk ved eit universitetssjukehus på grunn av eit samansett sjukdomsbilete. Ho hadde fjerna uterus pga. myom og fått diagnosen diskoid lupus med trombocytopeni seks år tidlegare. Hemoglobinnivået hadde $i$ fleire år vore rundt 18-19 g/10o ml. Ho hadde i lang tid hatt hovudverk, og det siste året hadde ho vore svcert slapp, hadde kjent seg kraftlaus og hatt smerter i ledda. Det siste halve året før konsultasjonen hadde ho hatt uklart syn og rennande og irriterte auge, utan at ho hadde observert puss. Pasienten hadde eitt år tidlegare vore undersøkt ved lokalsjukehuset for erytrocytose. Hjarte- og lungesjukdom var ikkje påvist og beinmargsutstryk var normalt. Ultralyd av buken hadde vist ein tumor $i$ venstre leverlapp. På CT-biletet var storleiken 7,5 ×6,5×6 cm. På grunn av lågt trombocyttal var det ikkje teke biopsi, men kontroll-CT to månader seinare ved lokalsjukehuset viste at storleiken ikkje var endra.

Pasienten hadde eit samansett sjukdomsbilete. På grunn av avvik i hematologiske prøvar var det planlagt å undersøkje beinmargen. Ved erytrocytose (auka tal erytrocyttar i blodet) kan serumnivået av erytropoietin gje nyttig informasjon om etiologien - høg verdi kan tyde at erytrocytosen er sekundær. Vanlegast er hjarte- og lungesjukdom, som gir hypoksi, men leversjukdom, nyresjukdom og einskilde svulsttypar kan òg føre til auka produksjon av erytropoietin.

Pasienten opplyste at dei naturlege funksjonane var som dei skulle vere. For hovudverken brukte ho ibuprofen tablettar. Ho røykte 10-15 sigarettar dagleg. Huda var grov og ru, relativt brunpigmentert. Desse endringane var lokalisert til både rygg, bryst og armar. I ansiktet, som var raudfarga (plethora), var det fleire små lyse, hudfarga heva parti på eit par millimeter i diameter og einskilde små, tydelege kar (teleangiektasi) (fig 1). Det var tydeleg karteikning i conjunctiva, som var tjukkare enn vanleg med nedslag av granulcert materiale. Neglesengene og munnslimhinne var blålilla.

Trommestikkfingrar (clubbing) vart notert. Blodtrykket var 155/100 mm Hg, pulsen 82. Status elles var utan merknader. 


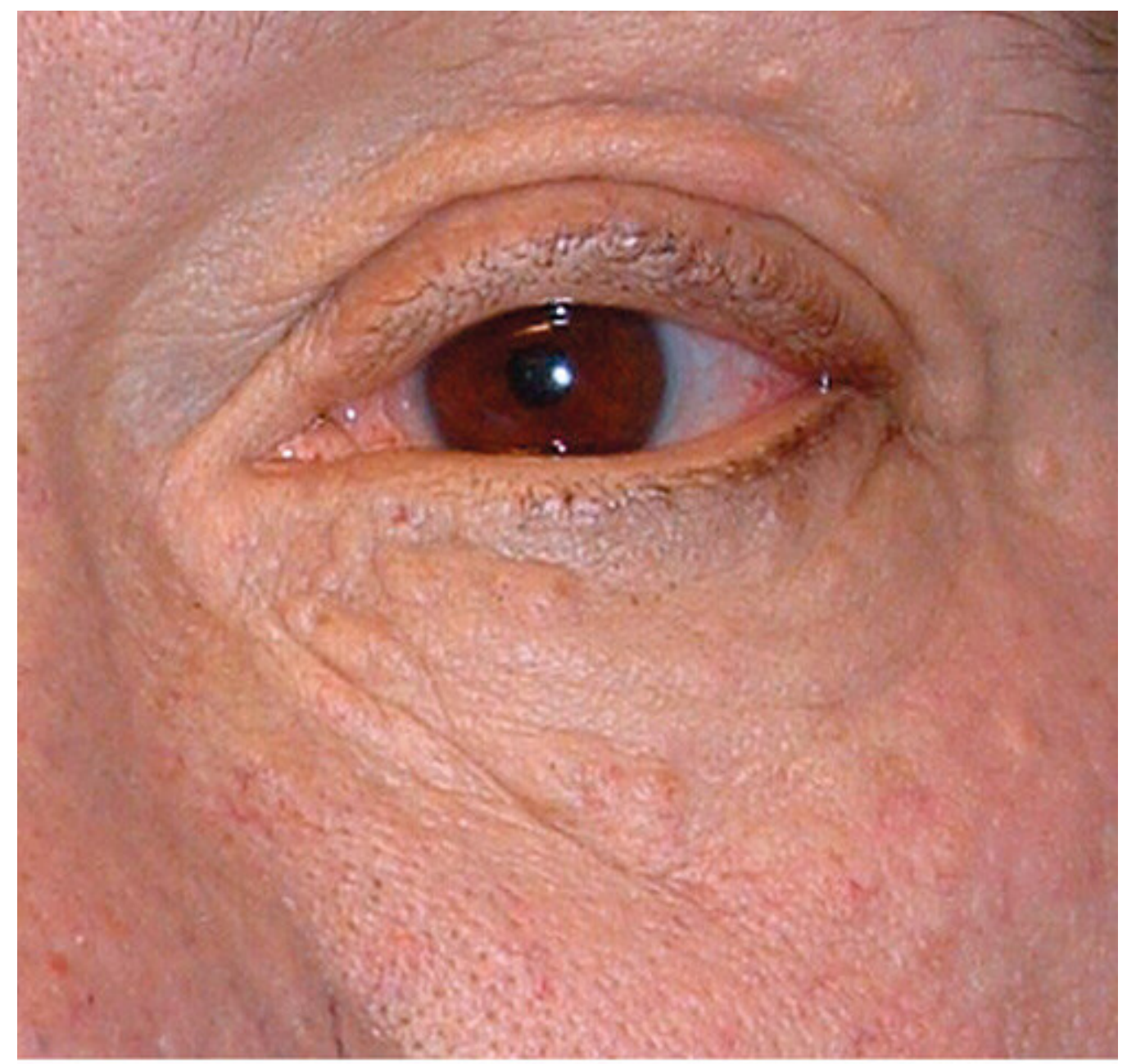

b

Figur 1 I huda var det talrike små knutar både på kroppen og i ansiktet. I conjunctiva ser ein karinjeksjon og einskilde små knutar

Endokrine avvik kan føre til hyperpigmentering og slapphet. Hudendringane kunne minne om små xantom, og lipidverdiane vart difor undersøkt. Trommestikkfingrar kunne gje mistanke om lunge- eller hjartesjukdom.

Blodprøvene viste hemoglobinkonsentrasjon på 17,4 g/10o ml (11,5-16,o g/10o ml), hematokrit 53 \% (35-45\%), leukocyttar $3,8 \cdot 10^{9} / l\left(4,0-11,0 \cdot 10^{9} / \mathrm{l}\right)$ og trombocyttar på $80 \cdot 10^{9} / l\left(150-450 \cdot 10^{9} / \mathrm{l}\right)$. Senkingsreaksjonen var $42 \mathrm{~mm} / \mathrm{t}(<28 \mathrm{~mm} / \mathrm{t}), C R P$-nivået $<5 \mathrm{mmol} / \mathrm{l}(<5 \mathrm{mmol} / \mathrm{l})$. Erytrocytose vart stadfesta med ein hematokritverdi over $\emptyset$ vre referansenivå. På grunn av høg senkingsreaksjon vart det gjort serumelektroforese og kvantitering av immunglobulin.

Blodutstryk viste erytrocytcer anisocytose (ulik storleik), normal fordeling av leukocyttar og trombocytopeni. Ved beinmargsaspirasjon vart det funne $25 \%$ plasmaceller. Cristabiopsi viste hypercellulcer beinmarg, hyperplasi av megakaryocyttane, men med normal morfologi. Det var rikeleg med normoblastar og forholdet mellom erytropoiese og myelopoiese var anslagsvis 1:1. Det var auka tal modne og til dels umodne plasmaceller.

Beinmargsbiopsien stadfesta funnet av plasmaceller. Vanlegvis dominerer myelopoesen i beinmarg, men hos pasienten vår var erytropoesen tydeleg stimulert. Hyperplasi av megakaryocyttane kunne tyde på auka nedbryting av blodplater. Dette kan ha mange årsaker, hos pasienten vår kunne eventuelt revmatologisk sjukdom, stor tumor i levra (hemangiom) eller immunologisk trombocytopenisk purpura vere aktuelt. 
Kolesterolnivået var 15,7 mmol/l (3,9-7,8 mmol/l), triglyseridnivået 31,4 $\mathrm{mmol} / \mathrm{l}(0,5-2,6 \mathrm{mmol} / \mathrm{l})$, HDL-kolesterolnivået 1,9 mmol/l (1,0-2,7 mmol/l) og LDL-kolesterolnivået o,5 mmol/l (2,0-5,3 $\mathrm{mmol} / \mathrm{l})$. Lipidelektroforesen viste eit dominerande diffust avgrensbart band i prebetaregionen som passa best med ein type III-hyperlipidemi. Albuminnivået var 26,8 $\mathrm{g} / \mathrm{l}(36, \mathrm{o}-45, \mathrm{og} / \mathrm{l})$ og totalproteinnivået $82,6 \mathrm{~g} / \mathrm{l}(64,0-79, \mathrm{og} / \mathrm{l})$. Histologisk undersøking av conjunctiva (fig $2 a)$ viste lipidrike makrofagar, og i hudbiopsien vart det sett kjempeceller, skumceller og betennelsesceller (fig $2 b)$. 

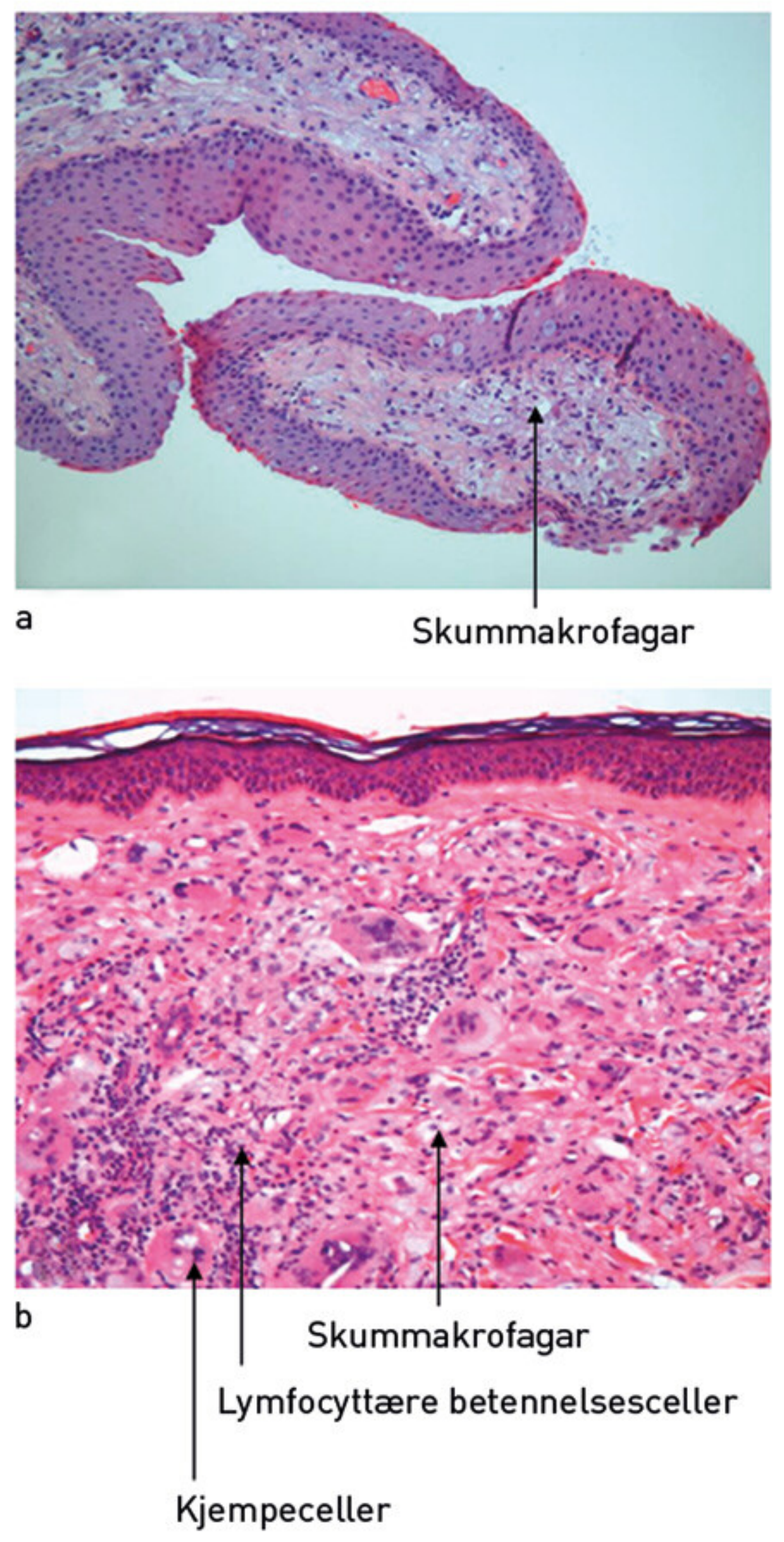
Figur 2 a) Biopsi frå conjunctiva viste avleiring av lipid i makrofagar. b) Hudbiopsi viste veldifferensiert epidermis, medan det i dermis var rikeleg med kjempeceller, skummakrofagar og lymfocytære betennelsesceller. Endringane i både conjunctiva og huda passar med diagnosen xantom/xantogranulom

Pasienten hadde alvorleg hyperlipidemi - med totalkolesterolnivå på $15 \mathrm{mmol} / \mathrm{l}$, triglyseridnivå på $30 \mathrm{mmol} / \mathrm{l}$ i serum og fettavleiring i huda. Hypertriglyseridemi $(>11$ mmol/l) kan utløyse akutt pankreatitt, slik at tiltak må settast i verk raskt for å redusere nivået. Hyperlipidemi kan vere sekundært til både sjukdom, som diabetes mellitus type 2, nefrotisk syndrom, kronisk nyresvikt, hypotyreose og kolestatisk leversjukdom, og til andre faktorar, som sigarettrøyking, alkoholmisbruk, overvekt og medikamentbruk (tiazid, $\beta$-blokkarar og peroral østrogenbehandling). Pasienten hadde røykt i 40 år, men sigarettrøyking kunne ikkje forklare den uttalte dyslipidemien. Sigarettrøyking vil kunne gje moderat reduksjon i serum-HDL-kolesterolnivå og kan indusere insulinresistens. Ingen av dei vanlege årsakene til sekundær dyslipidemi vart funne hos pasienten.

Kvinna vart lagt inn for vidare undersøking for myelomatose, erytrocytose og hyperlipidemi. Ho fasta og vart sett på behandling med atorvastatin $80 \mathrm{mg}$ (Lipitor) og eikosapentaensyre (EPA) og dokosaheksaensyre (DHA) kapslar (3 kapslar $\times 2$ (Omacor)). I løpet av få dagar fall triglyseridnivået til 13,5 mmol/l, amylasenivået var heile tida i normalområdet. Pasienten fekk etter kvart ete feittfattig kost. Lipoproteinlipaseaktiviteten i postheparinplasma (10o IU heparin/kg kroppsvekt) vart målt til $410 \mathrm{IE} / \mathrm{ml}$ ( $\mathrm{i}$ normalområdet). Genotyping av apolipoprotein $\mathrm{E}$ (ApoE) viste at ho var homozygot E3/3. EPA og DHA er essensielle feittsyrer som sett ned syntesen av triglyserid og VLDL-kolesterol, medan atorvastatin reduserer nivået av totalkolesterol, LDL-kolesterol, apolipoprotein B og triglyserid. ApoE er essensielt for normal katabolisme av triglyseridrike lipoprotein. Genotypen E2 (homozygot E2/E2) er assosiert med familiær hyperlipoproteinemi type III, som er karakterisert av auka konsentrasjon av kolesterol og triglyserid i serum, medan $\mathrm{E}_{3}$, som vart påvist hos pasienten vår, er den normale varianten.

Det vart ikkje påvist endokrin sjukdom som eventuelt kunne forklare hyperpigmenteringa. Revmatolog fann ikkje haldepunkt for at det kunne vere inflammatorisk revmatisk sjukdom. Ved serumelektroforese vart det påvist ein monoklonal komponent av IgG-kappatype. Total-IgG vart kvantitert til 34,9 g/l. Beta-2-mikroglobulin var 5,3 mg/l (1,4-3,2 mg/l). Bence-Jones' proteinuri på 834 $\mathrm{mg} / \mathrm{l}$ vart vist, medan vanleg røntgenunders $ø$ king av skjelettet ikkje viste osteolyse. Nyreprøver og elektrolyttar var alle i normalområdet, medan ASAT og ALAT var like over øvre referansegrense. Konsentrasjonen av erytropoietin i serum var på 68,6 IE/l (3,7-31,5 IE/l).

Diagnosen myelomatose vart stadfesta. Både albumin og beta-2-mikroglobulin har prognostisk verdi ved myelomatose, der lågt albuminnivå og høgt nivå av beta-2mikroglobulin er negative markørar.

Serum-erytropoietin over øvre referanseområde gav grunn til å tru at erytrocytosen var sekundær. Det var difor grunn til å gjere ny lunge- og hjarteundersøking, som var gjort eitt år tidlegare ved lokalsjukehuset, samt gjere radiologisk diagnostikk med tanke på erytropoietinproduserande tumor. Ved slike tumorar er ofte serumkonsentrasjonen svært høg, men ein tumor kan heller ikkje utelukkast ved ein konsentrajon like over øvre referansegrense, som hos pasienten vår (1).

CT caput viste ikkje noko patologisk intrakranialt, men små lytiske endringar i kraniet. CT thorax var normal, medan MR-undersøking stadfesta funn av solid tumor i levra, som lada kontrast og var uendra i storleik. Lungemedisinsk vurdering viste god lungefunksjon, med pO2 på 11,8 kPa og nattleg oksygenmetning over $92 \%$, trass $i 40$ år med røyking. Ekkokardiografien var normal. Det vart tatt biopsi av tumoren i levra, med spørsmål om mellom anna erytropoietinproduserande tumor, xantom eller adenom. Den histologiske diagnosen var adenom.

Det er godt dokumentert at hepatocellulære karsinom kan produsere erytropoietin. Det var mindre sannsynleg at pasienten vår hadde malign levertumor, på grunn av langvarig uendra storleik. Vi valde likevel å ta biopsi, mellom anna for å få vurdert produksjonen av erytropoietin. Immunhistokjemisk vart det påvist erytropoietin i adenomet (2). 
Det var indikasjon for behandling av myelomatosen, og pasienten fekk cyklofosfamid og deksametason - med god respons (fall i monoklonal komponent og reduksjon i plasmaceller $i$ beinmargen). Deretter vart det hausta autologe stamceller, og høgdosebehandling med autolog stamcellestøtte (HMAS) vart gjennomført. Totalkolesterolnivået var 3,7 mmol/l og triglyseridnivået 2,1 mmol/l før høgdosebehandlinga. Ved kontroll tre månader etter autolog stamcelletransplantasjon vart all lipidseinkande medikasjon stoppa.

Pasienten hadde i samband med cellegiftbehandlinga eit kortvarig fall i hemoglobinkonsentrasjonen, og hovudverken vart då borte. Det vart starta med venesectio etter at hemoglobinkonsentrasjonen steig til same nivå som før behandlinga med cellegift.

Ved kontroll 2,5 år etter høgdosebehandling med autolog stamcellestøtte hadde pasienten ingen plager. Hovudverken vart borte etter oppstart av venesectio med mål om å halde hematokritnivået under $0,45 \%$. Endringane $i$ huda var nesten borte, ho hadde klart syn og $i$ conjunctiva var det ingen karinjeksjon. Lupusliknande utslett hadde ho heller ikkje hatt.Blodplatetalet har halde seg $i$ underkant av $100 \cdot 10^{9} /$ l. Det var ingen hyperlipidemi, totalkolesterolnivået var 3,o $\mathrm{mmol} / \mathrm{l}(3,3-6,9$ mmol/l), HDL-kolesterolnivået 1,1 $\mathrm{mmol} / \mathrm{l}(1,0-2,7 \mathrm{mmol} / \mathrm{l}), \mathrm{LDL}$-kolesterolnivået $1,8 \mathrm{mmol} / \mathrm{l}(2,0-5,3$ $\mathrm{mmol} / \mathrm{l})$ og triglyseridnivået $0,5 \mathrm{mmol} / \mathrm{l}(0,5-2,6 \mathrm{mmol} / \mathrm{l})$.Ved serumelektorforese vart framleis monoklonalt IgG-kappa påvist, men totalkonsentrasjonen av $\operatorname{IgG}$ på 9,2 g/l var i normalområdet. Det var heller ingen auke av plasmaceller i beinmargen, slik at pasienten hadde ein god partiell respons etter behandlinga.

Malign transformasjon hos opptil $13 \%$ av pasientane med hepatocellulære adenom er rapportert (3).

Pasienten ynskte å få fjerna svulsten i levra, og ho vart henvist til operasjon 2,5 år etter at ho fekk høgdosebehandling med autolog stamcellestøtte. Erytropoietinkonsentrasjonen $i$ serum var ved kontrollmåling fire månader etter fjerning av svulsten normalisert, hemoglobinnivået var $i$ normalområdet og det hadde ikkje vore naudsynt å gjere venesectio.

Ved kontroll tre år etter høgdosebehandlinga var pasienten framleis $i$ god form, men totalkolesterolnivået hadde stige til 7,5 mmol/l og triglyseridnivået til 7,9 mmol/l. Kvantitering av immunoglobulin viste stigande IgG og aukande del plasmaceller i aspirat av beinmargen. Pasienten starta på ny med cytostatika og gjennomgjekk ny høgdosebehandling med autolog stamcellestøtte. Det vart ikkje gjeve lipidseinkande medikasjon. Allereie etter første induksjonskur med cyklofosfamid og deksametason var lipidverdiene fallande, og etter to behandlingssyklusar hadde totalkolesterolnivået falle til 3,6 mmol/l og triglyseridnivået til 1,6 mmol/l. Ved kontroll to år etter andre høgdosebehandling med autolog stamcellestøtte var pasienten framleis i fin form - med totalIgG på 7,8 g/l og totalkolesterol- og triglyseridnivå i nedre del av referanseområdet.

\section{Diskusjon}

Pasienten hadde uttalt dyslipidemi ved første konsultasjon. Ved primær hyperlipidemi med så høge lipidverdiar vil ein vente $h ø g$ insidens av hjarte- og karsjukdom i familien, men så var ikkje tilfellet hos denne pasienten. Genotyping av ApoE gav heller ikkje grunnlag for å tru at dette var familiært. Dei vanlege årsakene til sekundær hyperlipidemi vart ikkje påvist. Då pasienten hadde erytrocytose og høg senking, vart beinmargen unders $\emptyset$ kt og serumelektroforese utført. Diagnosen myelomatose vart stilt på grunnlag av monoklonal komponent av IgG-type i serum, osteolyse i kraniet og over $10 \%$ plasmaceller i beinmargen.

Ved myelomatose er lipidverdiane vanlegvis i normalområdet (4.) eller reduserte $(5, \underline{6})$. Ut frå litteraturen kan ein ved myelomatose sjå flate xantom trass i normale lipidverdiar (7.). Ved litteraturs $\varnothing \mathrm{k}$ vart det funne fleire kasuistikkar der det vart rapportert om monoklonal komponent som grunnen til hyperlipidemi (7.)-(르).

Pasienten fekk behandling med lipidsenkande medikasjon og feittfattig kosthald. Om lipidseinkande medikasjon åleine ville hatt særleg effekt hjå henne er usikkert, då det er rapportert om behandlingsresistens for lipidsenkande medikasjon ved denne tilstanden (7.). Ho starta med cellegift kort tid etter at diagnosen myelomatose vart stilt, og 
totalkolesterol- og triglyseridnivå fell parallelt med reduksjonen i den monoklonale komponenten. Låge lipidverdiar i stabil fase av myelomatosen og stigande verdiar ved progrediering av sjukdommen tre år etter høgdosebehandling med autolog stamcellestøtte, med nytt fall etter start med cytostatika, gjev grunn til å tru at det var ein kausal samanheng mellom den monoklonale komponenten og endringa i lipidomsetninga hos pasienten.

Omgrepet autoimmun hyperlipidemi (AIH) er brukt for å forklare denne tilstanden (13). Autoimmun hyperlipidemi vart definert som ein metabolsk sjukdom der antistoff bind seg til molekyl som tek del i transport og fjerning av plasmalipider. Fleire mekanismar er moglege: Redusert lipoproteinlipaseaktivitet er rapportert (14.), men hos pasienten vår vart det målt normal lipoproteinlipaseaktivitet. Dette kunne tyde på at hyperlipidemien skuldast manglande opptak av triglyseridrike lipoprotein i levra. Monoklonalt immunglobulin kan via binding til lipoproteinpartiklar hindre binding til reseptor på levercellene (7,15). Alternativt kan ein tenkje seg at antistoffa kan binde seg til reseptoren på levercellene og blokkere denne. Det er også rapportert om redusert hepatisk triglyseridlipaseaktivitet ved denne tilstanden (1ㅡ). Pasienten vår hadde ikkje svært høgt nivå av monoklonal komponent. Trass i vedvarande lågt nivå av monoklonal komponent etter avslutta cellegiftbehandling normaliserte lipidverdiane seg. Det kan tyde på at ein må over ein viss konsentrasjon av monoklonal komponent for å få ein blokkerande effekt. Denne konsentrasjonen vil truleg variere med affiniteten til antistoffet for det molekylet som antistoffet bind seg til.

Erytrocytosen var eit resultat av auka produksjon av erytropoietin. Det er rapportert at både nyrecellekarsinom, levercellekarsinom, leiomyom og cerebellare tumorar kan produsere erytropoietin. Vi har berre funne ein kasuistikk om erytropoietinproduserande adenom i lever (1). Dette var hos eit barn der erytropoietinkonsentrasjonen var like over $\emptyset v r e$ referansegrense. Etter fjerning av adenomet normaliserte hemoglobinkonsentrasjonen seg. Vår myelomatosepasient hadde ingen plager relatert til erytrocytose så lenge venesectio vart gjennomført. Eit par år etter at ho hadde fătt høgdosebehandling med autolog stamcellestøtte ynskte ho å få fjerna leversvulsten. Hemoglobinkonsentrasjonen har etter dette vore i normalområdet.

Trombocytopenien har vore stabil. Megakaryocytthyperplasi kunne tyde på auka nedbryting av blodplater. Det vart påvist eit adenom i levra, ikkje eit hemangiom, som teoretisk kunne gje trombocytopeni. Ved immunologisk trombocytopenisk purpura finn ein ofte megakaryocytthyperplasi i beinmargsbiopsi. I samband med cellegiftbehandlinga vart det også gjeve deksametason. Vi har ingen målingar av platetalet etter innleiande kurar med cyklofosfamid og deksametason. Derimot var platetalet over $130 \cdot 10^{9} /$ lto døgn etter høgdosebehandlinga med melfalan. Deksametason vart her nytta som kvalmestillande medikasjon. Dette kan eventuelt tyde på at trombocytopenien hadde immunologisk grunnlag.

Median alder ved myelomatose er omtrent 70 år, men det er stor variasjonsbreidd. Hyperlipidemi er ein sjeldan komplikasjon til myelomatose, men kasuistikken viser at hos menneske med mistenkt sekundær hyperlipidemi bør serumelektroforese gjerast dersom ein ikkje påviser ein av dei meir vanlege årsakene.

Pasienten har samtykka til publisering.

\section{LITTERATUR}

1. Marie-Cardine A, Schneider P, Greene V et al. Erythrocytosis in a child with a hepatic adenoma. Med Pediatr Oncol 2001;36: 659-61. [PubMed] [CrossRef]

2. Vik A, Cui G, Isaksen V et al. Erythropoietin production by a hepatic adenoma in a patient with severe erythrocytosis. Acta Haematol 2009; 121: 52-5. [PubMed] [CrossRef] 
3. Foster JH, Berman MM. The malignant transformation of liver cell adenomas. Arch Surg 1994; 129: 712-7. [PubMed] [CrossRef]

4. Feingold KR, Castro GR, Ishikawa Y et al. Cutaneous xanthoma in association with paraproteinemia in the absence of hyperlipidemia. J Clin Invest 1989; 83: 796-802. [PubMed] [CrossRef]

5. Riesen W, Noseda G. Antikörper gegen Lipoproteine beim Menschen. Vorkommen und biologische Bedeutung. Klin Wochenschr 1975; 53:353-61. [PubMed] [CrossRef]

6. Seitanidis BA, Shulman G, Hobbs JR. Low serum cholesterol with IgA-myelomatosis. Clin Chim Acta 1970; 29: 93-5. [PubMed] [CrossRef]

7. Burnside NJ, Alberta L, Robinson-Bostom L et al. Type III hyperlipoproteinemia with xanthomas and multiple myeloma. J Am Acad Dermatol 2005; 53 (suppl 1): S281-4. [PubMed] [CrossRef]

8. Kilgore LL, Patterson BW, Parenti DM et al. Immune complex hyperlipidemia induced by an apolipoprotein-reactive immunoglobulin A paraprotein from a patient with multiple myeloma. Characterization of this immunoglobulin. J Clin Invest 1985; 76: 225-32. [PubMed] [CrossRef]

9. Marien KJ, Smeenk G. Plane xanthomata associated with multiple myeloma and hyperlipoproteinaemia. Br J Dermatol 1975; 93: 407-15. [PubMed] [CrossRef]

10. Taylor JS, Lewis LA, Battle JD Jr et al. Plane xanthoma and multiple myeloma with lipoproteinparaprotein complexing. Arch Dermatol 1978; 114: 425-31. [PubMed] [CrossRef]

11. Feussner G, von Hodenberg E, Ziegler R. Atypical type III hyperlipoproteinemia in a patient with Ig A myelomatosis. Klin Wochenschr 1990; 68: 526-32. [PubMed] [CrossRef]

12. Nozaki S, Ito Y, Nakagawa T et al. Autoimmune hyperlipidemia with inhibitory monoclonal antibodies against low density lipoprotein binding to fibroblasts in a case with multiple myeloma. Intern Med 1997; 36: 920-5. [PubMed] [CrossRef]

13. Beaumont JL, Beaumont V. Autoimmune hyperlipidemia. Atherosclerosis 1977; 26: 405-18. [PubMed] [CrossRef]

14. Beaumont JL, Berard M, Antonucci M et al. Inhibition of lipoprotein lipase activity by a monoclonal immunoglobulin in autoimmune hyperlipidemia. Atherosclerosis 1977; 26: 67-77. [PubMed] [CrossRef]

15. Lewis LA, deVolfe VD, Butkus A et al. Autoimmune hyperlipidemia in a patient. Atherosclerotic course and changing immunoglobulin pattern during 21 years of study. Am J Med 1975; 59:208-18. [PubMed] [CrossRef]

Publisert: 29. mai 2012. Tidsskr Nor Legeforen. DOI: 10.4045/tidsskr.11.1056

Mottatt 27.9. 2011, første revisjon innsendt 25.2. 2012, godkjent 1.3. 2012. Medisinsk redaktør Are Brean. (C) Tidsskrift for Den norske legeforening 2023. Lastet ned fra tidsskriftet.no 26. april 2023. 